\title{
Utilization of the White-rot Fungus, Trametes menziesii for Landfill Leachate Treatment
}

\author{
(Penggunaan Kulat Busuk Putih, Trametes menziesii untuk Pengolahan Bahan Larut Lesap Tanah Isian)
}

\author{
W.A.R. WAN RAZARINAH*,M. NOOR ZALINA \& NOORLIDAH ABDULLAH
}

\begin{abstract}
The study monitored the characteristics of the leachate collected from ten different landfills and presented the experimental work for the treatment of leachate by immobilized Trametes menziesii. Variation in biological oxygen demand (BOD), chemical oxygen demand (COD) and ammoniacal nitrogen $\left(\mathrm{NH}_{3}-\mathrm{N}\right)$ showed that the age of the leachate has a significant effect on its characteristics and composition. The BOD /COD ratio tends to decrease as the age of leachate increases, varying from 0.71 for a relatively 'fresh' leachate to 0.62 for an older (more stabilized) one. Variations in the characteristics of the leachate suggested that these leachates are difficult to treat. The principal pollutants in the leachate samples were organic and ammonia loads. Treatment of leachate using immobilized Trametes menziesii achieved 89.14 and $2.11 \%$ removals for leachate $\mathrm{BOD}_{5}$ and $\mathrm{COD}$, respectively. These findings suggested that using immobilized Trametes menziesii can remove promising percentage of $B O D$ and $C O D$ leachate.
\end{abstract}

Keywords: BOD; COD; leachate; white-rot fungi

\section{ABSTRAK}

Pencirian bahan larut lesap daripada 10 tanah isian berbeza dan hasil eksperimen dalam pengolahan bahan larut lesap oleh kultur pegun Trametes menziesii telah dikaji. $\mathrm{BOD}_{5}, \mathrm{COD}$ dan $\mathrm{NH}_{3}-\mathrm{N}$ yang bervariasi menunjukkan bahawa usia bahan larut lesap memberikan kesan yang signifikan ke atas ciri dan kandungan bahan larut lesap. Nisbah BOD 5 /COD menunjukkan pengurangan apabila usia bahan larut lesap meningkat, ia 0.71 bagi bahan larut lesap yang 'muda' dan 0.62 bagi bahan larut lesap yang lebih berusia. Ciri-ciri bahan larut lesap yang bervariasi menyebabkan ia sukar untuk diolah. Bahan cemar yang utama dalam bahan larut lesap adalah bahan organik dan ammonia. Pengolahan bahan larut

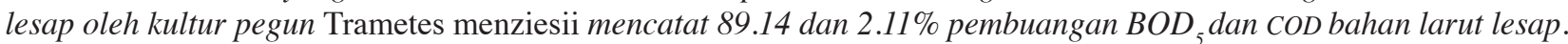
Penemuan ini mencadangkan bahawa penggunaan kultur pegun Trametes menziesii berupaya untuk menyingkirkan bahan larut lesap $\mathrm{BOD}_{5}$ dan COD dalam peratusan yang menggalakkan.

Kata kunci: Bahan larut lesap; BOD; COD; kulat busuk putih

\section{INTRODUCTION}

Increasing of solid wastes has become a major problem for the environment. Jemec et al. (2012) reported that according to EUROSTAT statistics from the year 2007, approximately 106 million tons (which yielding $522 \mathrm{~kg}$ / capita) of municipal waste was land-filled in the whole European. Land-filling is still a most common disposal alternative of municipal solidwaste in most countries like China (Ding et al. 2001) and Kuwait (Al-Muzaini 2006). Meanwhile in Malaysia, landfilling and disposing of wastes in non-sanitary landfill had been and is expected to remain as the most common method for the disposal of municipal solid wastes. According to Kamaruddin et al. (2014), among 261 landfills in Malaysia, more than $80 \%$ of them are open dump. A major problem arising from landfills is the discharge of leachate. Due to the high amounts of precipitation, large quantities of leachate (liquid discharge from solid waste) from landfills in tropical climates are to be expected. According to Edi Munawar and Fellner (2013), an annual leachate generation rate of more than 1000 litres per $\mathrm{m}^{2}$ was frequently observed in tropical countries.

Landfill leachate is formed by water that passed through the waste layers and thus contains various types of pollutants. The subsequent movement of the landfill leachates into the surrounding soil, ground water or surface water could lead to severe pollution. Landfill leachate is a complex mixture of inorganic and organic substances. Kjeldsen et al. (2002) summarized the most common constituents of leachates based on several biological and chemical analyses performed on landfill leachates that come from different industrial origins. These include dissolved organic matter, inorganic macro components (e.g., $\mathrm{Ca}^{2+}, \mathrm{Mg}^{2+}, \mathrm{K}^{+}$and $\mathrm{Fe}^{2+}$ ), heavy metals and xenobiotic organic compounds originating from household or industrial chemicals e.g. aromatic hydrocarbons, phenols, chlorinated aliphatics and pesticides (Baun et al. 2004). However, in general, leachate may contain high concentrations of dissolved organic matter and inorganic macro components which may vary due to varieties of 
influencing factors. Jemec et al. (2012) stated that the components of leachate depend on the stabilization stage of the landfill and seasonal variation. They reported that based on physicochemical characterization, the properties of leachates collected at different periods of the year vary considerably. In addition, Kim et al. (2003) stated that the characteristics of leachate depends on factors such as hydrogeology, waste composition, amount of rainfall, the landfill method and the age of the landfill (e.g. active or closed landfill).

Leachate composition is an indication of the type of waste disposed and the processes which occur within the landfill (Slack et al. 2005). Al-Muzaini (2006) stated the complex chemical and biological reactions that take place in a landfill site make it difficult to predict the quality of leachate at any given landfill site. However, Marttinen et al. (2002) stated that the characteristic of the leachate is one of the factors used to determine the applicability of a treatment in most cases. Therefore, the characteristic of the leachate is a critical factor in establishing a corresponding effective treatment process. Hence, to treat leachate, it is very important to determine the characteristic of that leachate.

Several options have been put into practise for leachate treatment, presenting varying degree of efficiency (Kamaruddin et al. 2014). Biological processes based upon suspended-growth biomass, were proved to be effective for the removal of organic carbon and nutrients content (Zoubolis et al. 2001). White-rot fungi are of current interest to be used for the bioremediation of a broad spectrum of persistent xenobiotics. Whiterot basidiomycetous fungi have been implicated in the transformation of a large amount of organopollutants structurally related to lignin for example Pycnoporus sanguineus, Coriolus pubescens and Trametes sp. in degradation of lignosulphonates (Eugenio et al. 2008) and Phanerochaete chrysosporium, Pleurotus sp. and Trametes versicolor in mineralizing polycyclic aromatic hydrocarbons (PAH) (Pointing 2001). Besides that, Polak and Jarosz-Wilkołazka (2010) also stated that the use of fungal cultures to transform various chemical compounds had been reported in several studies. White rot fungi were able to produce extracellular lignin peroxidase (LiP) and manganese-dependent peroxidase that is essential for lignin degradation (Leonowicz et al. 1999). These enzymes are able to oxidize a variety of high-priority aromatic pollutants such as polycyclic aromatic hydrocarbons, chloromatics and polyaromatic dyes (Kotterman et al. 1996). Saetang and Babel (2009) have applied immobilized $T$. versicolor to treat landfill leachate in column experiments since the immobilization is expected to improve the mass transfer of oxygen and nutrients for fungal mycelia by providing a large attaching surface area. Besides that, Saetang and Babel (2010) stated that the advantages of using immobilized microorganism for pollutant degradation is due to their economically cheaper, easier to handle and the immobilized fungus is reusable for several batches.
In this paper we focused on investigating the level of selected parameters in the raw leachate collected from various types of landfills and compare the changes of leachate composition from both old (closed) landfills and landfills still in use (active landfills). With the information of leachate component obtained, biological method by immobilized fungi was applied for leachate treatment in order to meet the discharge standards.

\section{MATERIALS AND METHODS}

\section{LANDFILL DESCRIPTION}

Leachates samples were collected from ten different landfills listed in Table 1. The landfills received wastes within the municipality area. Three of the landfills (Nos. 1-3) were engineered/sanitary (i.e. with liners and leachate collection systems), while seven others (Nos. 4-10) were dumpsites/non-sanitary (i.e. without liners and leachate collection system) landfills. Among three sanitary landfills, two were active (Nos. 1-2) and another one was a closed landfill (Nos. 3). Among the seven non-sanitary landfills, landfills Nos. 4-5 were active landfills and landfills Nos. 6-10 were closed landfills.

\section{SAMPLING PROCEDURE}

Leachate samples were collected from existing ponds. Leachate collection ponds servicing the whole landfill were sampled at all the sanitary landfills (Nos. 1-3). At the non-sanitary landfills no such collection ponds were installed hence, samples were collected from leachate flowing out below the Landfills Nos. 4-10. At all landfills, the sampling bottles were lowered into the pond in order to collect leachate. All samples were collected in plastic bottles. The samples were packed in cool boxes $\left(8-15^{\circ} \mathrm{C}\right)$ and were transported to the laboratory for analysis.

\section{ANALYSIS OF LEACHATE}

The leachate was characterized based on several pollution parameters as required by Environmental Quality Act (EQA) (2009) i.e. biological oxygen demand (BOD), chemical oxygen demand (COD), total organic carbon (TOC), total nitrogen (TN), total suspended solid (TSS), ammoniacal-nitrogen $\left(\mathrm{NH}_{3}-\mathrm{N}\right), \mathrm{pH}$ and also heavy metals such as: magnesium, lead, copper, iron, zinc and cadmium. The techniques used for sampling and analyses were in accordance with the Standard Method for the Examination of Water and Wastewater (APHA 1998). The Hach DR 2800 spectrophotometer was used for the determination of chemical concentration. The experiment was replicated three times to obtain an average. All the experiments were undertaken at $20 \pm 2^{\circ} \mathrm{C}$.

\section{FUNGI AND SUB-CULTURE OF FUNGI}

Trametes menziesii was obtained from the Mycology Laboratory, Institute of Biological Sciences, University 
TABLE 1. General characteristics of the Municipal solid wastes (MSW) landfills included in the study

\begin{tabular}{|c|c|c|c|c|c|}
\hline $\begin{array}{l}\text { Landfill } \\
\text { No. }\end{array}$ & Location & $\begin{array}{l}\text { Type of landfill } \\
\text { (closed/active) }\end{array}$ & $\begin{array}{l}\text { Landfill area } \\
\text { (acre) }\end{array}$ & $\begin{array}{l}\text { Period of } \\
\text { operation }\end{array}$ & Type of waste \\
\hline 1 & *Jeram, Kuala Selangor & $\begin{array}{l}\text { Sanitary } \\
\text { (active) }\end{array}$ & 160 & $2007-$ & $\begin{array}{l}\text { Domestic waste }(95 \%) \text {, } \\
\text { Others }(5 \%)\end{array}$ \\
\hline 2 & $*$ Tanjung 12 , Sepang & $\begin{array}{l}\text { Sanitary } \\
\text { (active) }\end{array}$ & 160 & $2010-$ & $\begin{array}{l}\text { Domestic waste }(96 \%) \text {, } \\
\text { Industrial }(3 \%) \text {, Others (1\%) }\end{array}$ \\
\hline 3 & *Air Hitam, Puchong & Sanitary (closed) & 100 & $1995-2006$ & Domestic waste \\
\hline 4 & Sg Besar, Sabak Bernam & $\begin{array}{l}\text { Non-sanitary } \\
\text { (active) }\end{array}$ & 10 & NA & Domestic waste \\
\hline 5 & $\begin{array}{l}\text { Bukit Beruntung, Hulu } \\
\text { selangor }\end{array}$ & $\begin{array}{l}\text { Non-sanitary } \\
\text { (active) }\end{array}$ & NA & NA & Domestic waste \\
\hline 6 & $\begin{array}{l}\text { Teluk Kapas, Rantau } \\
\text { Panjang, }\end{array}$ & $\begin{array}{l}\text { Non-sanitary } \\
\text { (closed) }\end{array}$ & 32.4 & $2000-2003$ & Domestic waste \\
\hline 7 & $\begin{array}{l}\text { Teluk Gong, } \\
\text { Pandamaran }\end{array}$ & $\begin{array}{l}\text { Non-sanitary } \\
\text { (closed) }\end{array}$ & 19.42 & $1986-2000$ & Domestic waste \\
\hline 8 & Kundang, Selayang & Non-sanitary (closed) & NA & NA & Domestic waste \\
\hline 9 & Batu 20, Rawang & Non-sanitary (closed) & NA & NA & Domestic waste \\
\hline 10 & $\begin{array}{l}\text { *Kubang Badak, Kuala } \\
\text { Selangor }\end{array}$ & $\begin{array}{l}\text { Non-sanitary } \\
\text { (closed) }\end{array}$ & 30 & 2006-2007 & Domestic waste \\
\hline
\end{tabular}

Sanitary: Engineered landfill with liners and leachate collection system; Non-sanitary: Uncontrolled landfills without liners and leachate collection system; NA: Not available. (Source: Department of Local Government 2003; *Sanitary landfills 2009)

of Malaya, Malaysia. The fungi were maintained on malt extract (MEA) (Oxoid) agar slants and the inoculum was prepared by sub-culturing onto MEA grown for 7 days at $28 \pm 2{ }^{\circ} \mathrm{C}$. Sub-culture was done once a week to obtain active fungi.

\section{MYCELIAL SUSPENSION AND IMMOBILIZATION OF FUNGI ON ECOMAT}

Mycelial suspension Four plugs (6- $\mathrm{mm}^{2}$ diameter) of a 7 -day old fungal colony growing in MEA media in Petri plates were transferred into $250 \mathrm{~mL}$ Erlenmeyer culture flasks containing $100 \mathrm{~mL}$ of Glucose-yeast-malt-peptone (GYMP) growth medium under sterile conditions. The GYMP growth medium contained the following: $\mathrm{MgSO}_{4} \cdot 7 \mathrm{H}_{2} \mathrm{O}$ $(1.00 \mathrm{~g} / \mathrm{L}) ; \mathrm{KH}_{2} \mathrm{PO}_{4}(1.00 \mathrm{~g} / \mathrm{L}) ; \mathrm{K}_{2} \mathrm{HPO}_{4}(1.00 \mathrm{~g} / \mathrm{L}) ; \mathrm{NH}_{4} \mathrm{Cl}$ $(1.00 \mathrm{~g} / \mathrm{L})$; Glucose $(15.00 \mathrm{~g} / \mathrm{L})$; Peptone $(8.00 \mathrm{~g} / \mathrm{L})$; Yeast Extract $(8.00 \mathrm{~g} / \mathrm{L})$ and Malt Extract $(8.00 \mathrm{~g} / \mathrm{L})$. Inoculated flasks were then agitated on an orbital shaker for $48 \mathrm{~h}$ at $28 \pm 2^{\circ} \mathrm{C}$ at $150 \mathrm{rpm}$.

Ecomat sterilization 50 pieces of Ecomat were put into $500 \mathrm{~mL}$ beaker. The beaker was covered with aluminium foil and then sterilized in autoclave for $1 \mathrm{~h}$ prior to use.

Fungi immobilization on Ecomat Four pieces of sterilized Ecomat and $5 \mathrm{~mL}$ of mycelia suspension were added to 250 $\mathrm{mL}$ Erlenmeyer culture flasks containing $50 \mathrm{~mL}$ of GYMP growth medium. The flasks were agitated at $100 \mathrm{rpm}$ on an orbital shaker. The Ecomat covered with fungal mycelium within 4 days were used for the study.

\section{EXPERIMENTAL DESIGN OF LEACHATE TREATMENT BY IMMOBILIZED TRAMETES MENZIESII}

Leachate characterization before treatment Leachate sample used in this study was collected from the pond of untreated leachate at the sanitary landfill. The leachate was filtered to remove suspended solids before measurement and was analyzed for $\mathrm{pH}, \mathrm{COD}, \mathrm{BOD}_{5}$ and $\mathrm{NH} 3-\mathrm{N}$.

Leachate treatment by immobilized T. menziesii The experiment was carried-out in $250 \mathrm{~mL}$ Erlenmeyer culture flasks; $125 \mathrm{~mL}$ of leachate was treated with immobilized T. menziesii on Ecomat. The flasks were then agitated on an orbital shaker for 28 days at $28 \pm 2^{\circ} \mathrm{C}$ at $150 \mathrm{rpm}$. At weekly time intervals (day 7, 14, 21 and 28), the value of $\mathrm{BOD}_{5}, \mathrm{COD}, \mathrm{pH}$ and ammoniacal nitrogen were analyzed. All processes were done under sterile conditions at ambient temperature.

Determination of leachate characteristics after treatment Removal of BOD, $\mathrm{COD}$ and $\mathrm{NH}_{3}-\mathrm{N}$ were investigated after fungal treatment and the results were compared with the initial value.

\section{RESULTS AND DISCUSSION}

Characteristics of the leachate content is one of the most important criteria to be determined before establishing the most suitable method for treating and disposing of any given pollutant. These analytical methods are required to assess the polluting strength of the waste. According to the EQA Standard 1974 (2009) and Waites et al. (2001), 
the tests usually include the determination of BOD, COD, TSS and TS. However, other tests may also be performed in order to determine the levels of specific components such as nitrogen, phosphorus and heavy metals.

Landfills can be either non-sanitary or sanitary landfill. This preliminary study was conducted in order to get the base data of leachate characteristics collected from different landfills that either closed or active and either non-sanitary or sanitary landfill. Table 1 shows that the landfills were in various range of operation duration time. It is between 3 and 27 years. The sources of solid waste in Malaysia usually generated by residential, commercial, institutional, construction, municipal services, treatment plant site, industrial and agriculture. Unfortunately, most of the wastes are dumped at non-sanitary landfill with improper record on the total amount and type of waste due to the uncontrolled manner of waste disposal during the early 1980's except for sanitary landfills.

The characterization of the landfill leachates in terms of general chemical parameters showed that there are huge differences between the landfills (Table 2 ). For instance, the total nitrogen concentrations were varied from 6.0 to $1700 \mathrm{mg} / \mathrm{L}$, the total suspended solids were varied from 10 to $3000 \mathrm{mg} / \mathrm{L}$ and correspondingly the observed concentrations of ammoniacal nitrogen were varied from $0.94 \mathrm{mg} / \mathrm{L}$ up to the extremely high concentration of $3200 \mathrm{mg} / \mathrm{L}$ in the leachate from Landfill No. 3. The concentration of total organic carbon was $12.0-45070 \mathrm{mg} / \mathrm{L}$ and not detected in the leachate from Landfill No. 9, while the $\mathrm{pH}$-values were varied from 6.29 to 8.39. The value of $\mathrm{BOD}_{5}$ was lower for all the leachate collected from non-sanitary landfills than in leachate collected from sanitary landfills. The values of $\mathrm{BOD}_{5}$ for leachate from closed non-sanitary landfills were $171 \pm 18.36$ mg/L (Landfill No. 6), 369 \pm 32.97 mg/L (Landfill No. 7), $81 \pm 6.24 \mathrm{mg} / \mathrm{L}$ (Landfill No. 8) and from closed sanitary landfill is $2497 \pm 221.31 \mathrm{mg} / \mathrm{L}$ (Landfill No. 3). Leachate from active non-sanitary Landfill No. 4 has BOD $_{5}$ value of $1160 \pm 98.49 \mathrm{mg} / \mathrm{L}$, while leachate from active sanitary Landfill No. 1 and Landfill No. 2 have BOD $_{5}$ value of $11360 \pm 703.42 \mathrm{mg} / \mathrm{L}$ and $1971 \pm 16.46 \mathrm{mg} / \mathrm{L}$, respectively. Similar patterns were shown for the COD value for leachate from non-sanitary and sanitary landfill.

The results suggested that leachates from the nonsanitary landfills (Nos. 4-10) generally had lower values than sanitary for all tested parameters, except for the $\mathrm{pH}$-values. This may be due to the method of leachate collection and other different factors such as amount and composition of waste. However, these results are within the ranges generally observed in landfills (Kjeldsen et al. 2002). In addition, Chu et al. (1994) stated that chemical properties of leachate samples from different landfills vary widely. They were affected by the amount of waste disposal on landfill, composition and moisture content of the refuse; hydrogeology and climate of the site; age and height of the landfill and season of the year. On top of that, it is also found that the leachate produced from landfills is a high strength of organic wastewater which, when discharged directly to a municipal wastewater treatment plant, may cause corrosion of the pump station, difficulty in maintaining constant effluent chlorine residual, and sludge bulking and settling problems (Deng 2007). Biological activity within landfill influence chemical concentration levels of the landfill. Particularly, at the onset of biodegradation processes the high organic and moisture contents resulted in an extremely strong leachate,

TABLE 2. Characteristics of landfill leachates with respect to general chemical parameters

\begin{tabular}{|c|c|c|c|c|c|c|}
\hline \multirow{2}{*}{ Parameter } & \multirow{2}{*}{ *Standard } & \multicolumn{5}{|c|}{ Landfill No. } \\
\hline & & 1 & 2 & 3 & 4 & 5 \\
\hline $\mathrm{BOD}_{5}(\mathrm{mg} / \mathrm{L})$ & 20 & $11360 \pm 703.42$ & $1971 \pm 16.46$ & $2497 \pm 221.31$ & $1160 \pm 98.49$ & $1120 \pm 73.43$ \\
\hline COD $(\mathrm{mg} / \mathrm{L})$ & 400 & $16000 \pm 1130.62$ & $6050 \pm 44.44$ & $4000 \pm 312.77$ & $2982 \pm 308.64$ & $2371 \pm 222.71$ \\
\hline TSS (mg/L) & 50 & $130 \pm 13.45$ & $570 \pm 27.40$ & $800 \pm 14.53$ & $3000 \pm 146.27$ & $320 \pm 22.91$ \\
\hline $\mathrm{NH}_{3}-\mathrm{N}(\mathrm{mg} / \mathrm{L})$ & 5 & $21.3 \pm 3.18$ & $17.2 \pm 1.73$ & $3200 \pm 185.00$ & $29.0 \pm 3.61$ & $2.2 \pm 4.00$ \\
\hline $\mathrm{TOC}(\mathrm{mg} / \mathrm{L})$ & NA & $4700 \pm 145.26$ & $11100 \pm 1056.42$ & $45070 \pm 1044.46$ & $281 \pm 16.70$ & $247 \pm 13.00$ \\
\hline $\mathrm{TN}(\mathrm{mg} / \mathrm{L})$ & NA & $98 \pm 13.45$ & $50 \pm 6.08$ & $1700 \pm 149.66$ & $119 \pm 6.24$ & $54 \pm 5.57$ \\
\hline $\mathrm{pH}$ & $6.0-9.0$ & $8.05 \pm 0.05$ & $8.07 \pm 0.03$ & $8.19 \pm 0.17$ & $8.39 \pm 0.11$ & $7.27 \pm 0.07$ \\
\hline \multirow{2}{*}{ Parameter } & \multirow{2}{*}{ *Standard } & \multicolumn{5}{|c|}{ Landfill No. } \\
\hline & & 6 & 7 & 8 & 9 & 10 \\
\hline $\mathrm{BOD}_{5}(\mathrm{mg} / \mathrm{L})$ & 20 & $171 \pm 18.36$ & $369 \pm 32.97$ & $81 \pm 6.24$ & $56 \pm 8.18$ & $925 \pm 6.00$ \\
\hline $\mathrm{COD}(\mathrm{mg} / \mathrm{L})$ & 400 & $455 \pm 33.15$ & $385 \pm 12.29$ & $165 \pm 16.09$ & $285 \pm 37.24$ & $2880 \pm 128.55$ \\
\hline TSS (mg/L) & 50 & $50 \pm 15.72$ & $50 \pm 6.08$ & $10 \pm 4.36$ & $130 \pm 13.86$ & $200 \pm 17.58$ \\
\hline $\mathrm{NH}_{3}-\mathrm{N}(\mathrm{mg} / \mathrm{L})$ & 5 & $2.6 \pm 0.82$ & $10.0 \pm 2.65$ & $0.94 \pm 0.19$ & $5.0 \pm 2.00$ & $650 \pm 8.89$ \\
\hline TOC (mg/L) & NA & $12 \pm 2.00$ & $27 \pm 4.00$ & $15 \pm 2.65$ & ND & $23000 \pm 836.48$ \\
\hline $\mathrm{TN}(\mathrm{mg} / \mathrm{L})$ & NA & $6 \pm 2.00$ & $102 \pm 21.63$ & $8 \pm 2.65$ & $32 \pm 9.16$ & $600 \pm 43.30$ \\
\hline $\mathrm{pH}$ & $6.0-9.0$ & $6.76 \pm 0.05$ & $7.54 \pm 0.06$ & $7.02 \pm 0.17$ & $6.29 \pm 0.25$ & $8.30 \pm 0.11$ \\
\hline
\end{tabular}

ND: Not detected

NA: Not available

* Source: The EQA (2009) 
which can affect the leachate treatment facility (Bilgili et al. 2007),

Besides comparing the characteristics of leachate from different types of landfills, the characteristics of leachate from active and closed landfills were also compared. The comparison was significant to identify the status of the pollutant resulting from the landfills even though it has been closed for several years. This is due to Kjeldsen et al. (2002) who stated that even after a landfill stops accepting waste and a final cover is placed over the landfill, the waste will continue to decompose. As an example, Chu et al. (1994) reported that ammoniacal nitrogen remained the mean values between 500 and $1500 \mathrm{mg} / \mathrm{L}$ for at least 50 years.

From the results shown in Table 3 , it shows that the characteristics of leachate from two active landfills i.e. sanitary (No. 1) and non-sanitary (No. 4) while, two were closed landfills i.e. sanitary (No. 3) and Landfill No. 10 (non-sanitary). The composition of leachate shows that almost all the studied parameters of the leachate from closed landfills were lower than the leachate from active landfills except $\mathrm{pH}$ and ammoniacal nitrogen. These may be due to biological and chemical composition of the landfill. Measurement of BOD and COD shows the organic acid content in leachate. The value of $\mathrm{BOD}_{5}$ for the leachate of closed landfills (No. 3: 2497 \pm 221.31 and No. 10: 925 \pm 6.00 $\mathrm{mg} / \mathrm{L}$ ) were lower than leachate of active landfills (No. 1: $11360 \pm 703.42$ and No. 4: $1160 \pm 98.49 \mathrm{mg} / \mathrm{L})$. Similar findings were obtained for the COD value where the values for leachate from closed landfills i.e. No. 3: 4000 \pm 312.77 and No. 10: $2880 \pm 128.55 \mathrm{mg} / \mathrm{L}$ were lower than COD value for leachate from active landfills i.e. No. 1: $16000 \pm 1130.63$ and No. 4: $2982 \pm 308.64 \mathrm{mg} / \mathrm{L}$. This study showed that the leachate from closed landfills of both sanitary and nonsanitary has lower biological oxygen demand $\left(\mathrm{BOD}_{5}\right)$ and chemical oxygen demand (COD) content compared with leachate from active landfills. This finding is parallel with the report by Kang et al. (2002) which stated that, organic concentration (measured as BOD and COD) decreased as the landfilling age increased. In addition, Miller and Clesceri (2003) stated that for waste sites (landfills) of longer standing (inactive or closed), COD and BOD levels in leachate may be less than the value for young leachate (which collected from active landfill). However, they generally exceed levels found in wastewaters, thus cannot be discharged to the surrounding environment.

The changes in leachate biodegradability are mainly reflected by the $\mathrm{BOD}_{5} / \mathrm{COD}$ ratio, as $\mathrm{BOD}_{5}$ is a direct measurement of the treatability of wastewater by the application of biological processes. Ratios of leachate $\mathrm{BOD}_{5} / \mathrm{COD}$ can be used to predict the effectiveness of various biological and physical-chemical processes for leachate treatment (Samudro \& Mangkoedihardjo 2010). Table 3 shows the $\mathrm{BOD}_{5}$ to $\mathrm{COD}$ ratio was reduced from 0.71 of young-landfill (Landfill No. 1) to 0.62 of oldlandfill (Landfill No. 3). This represents the decrease in biodegradability of the leachates with respect to their age. However this small amount of differences may be due to the factor that the closed landfill was only stopped receiving the waste just three years before the sample collection. These observations are coherent with findings by El-Fadel et al. (2002) that stated the BOD/COD ratio can be considered as a measure of the biodegradability of the organic matter, which typically decrease with time. Therefore, according to Tatsi and Zouboulis (2002) the observed decrease in $\mathrm{BOD}_{5} / \mathrm{COD}$ ratio represents a more complete oxidation of organic carbon; hence, it becomes less readily available as an energy source for microbial growth.

Meanwhile, the Table also show that the content of ammonium-nitrogen for leachate collected from closed landfills (No.10: $650 \pm 8.89 \mathrm{mg} / \mathrm{L}$ ) was higher compared with the amount of leachate from active landfills (No.1: $21.3 \pm 3.17 \mathrm{mg} / \mathrm{L})$. The ammonia concentration in aged leachate showed higher concentration than in young leachate that may be due to biological activities such as deamination of amino acids during destruction of original organic compounds (Faeiza et al. 2004). Tatsi and Zouboulis (2002) stated the great majority of total Kjeldahl nitrogen (TKN) content was found in ammoniacal form. Therefore, ammonia is the principal pollutant of 'old' leachate samples. Table 3 shows the ranged of $\mathrm{pH}$ was from 8.05 to 8.30 . The $\mathrm{pH}$ for the leachate from active sanitary landfill (No. 1) was $8.05 \pm 0.05$ while the $\mathrm{pH}$ value for the leachate from closed sanitary landfill (No. 3) was $8.19 \pm 0.17$. The results showed that the $\mathrm{pH}$ of leachate increased in the closed landfills (=older age landfill). These results are consistent with several other previous reports on the same subject. Faeiza et al. (2004) reported a study in Hong Kong detected that $\mathrm{pH}$ for 3.5 years of closed landfills ranged from 7.2 to 8.0 and $\mathrm{pH}$ for a 1.5 year closed landfill was only at 5.8. The finding was supported by Chu et al. (1994) who stated that $\mathrm{pH}$ of leachate increased with time due to the decrease of the concentration of partially ionized free volatile fatty acid over the age.

However, the result for other parameters such as total suspended solids and total nitrogen were varied in leachate. Similar results were found by Tatsi and Zouboulis (2002) where the concentration of the total dissolved solids (TDS) fluctuates widely.

The results showed that the concentrations of all tested heavy metals in the leachate landfill were below the standards levels, except for $\mathrm{Pb}(0.5 \pm 0.17 \mathrm{mg} / \mathrm{L})$ and $\mathrm{Fe}$ $(10.41 \pm 0.74 \mathrm{mg} / \mathrm{L})$ for Landfill No. 10 . The comparison of heavy metals concentrations in leachate from active landfill (Landfill No. 1) and closed landfill (Landfill No. 3) shows that the concentration of heavy metals was higher in leachate from closed landfill than in leachate from active landfill except for Fe. The concentrations of $\mathrm{Pb}$ were $0.11 \pm 0.01 \mathrm{mg} / \mathrm{L}$ for Landfill No. 3 and $0.06 \pm 0.02$ $\mathrm{mg} / \mathrm{L}$ for Landfill No. 1; the concentrations for $\mathrm{Zn}$ were $0.19 \pm 0.03 \mathrm{mg} / \mathrm{L}$ for Landfill No. 3 and $0.18 \pm 0.03 \mathrm{mg} / \mathrm{L}$ for Landfill No. 1 and the concentrations for $\mathrm{Mg}$ were $180.79 \pm 5.31 \mathrm{mg} / \mathrm{L}$ for Landfill No. 3 and $23.01 \pm 0.90 \mathrm{mg} / \mathrm{L}$ for Landfill No. 1. Meanwhile, the concentrations of Fe were $2.62 \pm 0.11 \mathrm{mg} / \mathrm{L}$ for Landfill No. 3 and $4.44 \pm 0.11$ 
TABLE 3. Comparison of leachate characteristics from active and closed landfills based on selected pollution parameters

\begin{tabular}{|c|c|c|c|c|c|}
\hline \multirow[b]{3}{*}{ Parameter /Landfill No. } & \multirow[b]{3}{*}{ Standard } & \multicolumn{2}{|c|}{ Sanitary } & \multicolumn{2}{|c|}{ Open dump } \\
\hline & & (Active) & (Closed) & (Active) & (Closed) \\
\hline & & 1 & 3 & 4 & 10 \\
\hline $\begin{array}{l}\text { Biochemicals oxygen demand } \\
\left(\text { BOD) } @ 20^{\circ} \mathrm{C}, 5 \text { Days }(\mathrm{mg} / \mathrm{L})\right.\end{array}$ & 20 & $11360 \pm 703.42$ & $2497 \pm 221.31$ & $1160 \pm 98.49$ & $925 \pm 6.00$ \\
\hline $\begin{array}{l}\text { Chemical oxygen demand } \\
(\mathrm{COD})(\mathrm{mg} / \mathrm{L})\end{array}$ & 400 & $16000 \pm 1130.62$ & $4000 \pm 312.77$ & $2982 \pm 308.64$ & $2880 \pm 128.55$ \\
\hline $\mathrm{BOD}_{5} / \mathrm{COD}$ & NA & $0.71 \pm 0.08$ & $0.62 \pm 0.09$ & $0.39 \pm 0.05$ & $0.32 \pm 0.07$ \\
\hline $\begin{array}{l}\text { Total suspended solids } \\
(\mathrm{TSS})(\mathrm{mg} / \mathrm{L})\end{array}$ & 50 & $130 \pm 13.45$ & $800 \pm 14.55$ & $3000 \pm 146.27$ & $200 \pm 17.58$ \\
\hline $\begin{array}{l}\text { Ammoniacal nitrogen } \\
\left(\mathrm{NH}_{3} \mathrm{~N}\right)(\mathrm{mg} / \mathrm{L})\end{array}$ & 5 & $21.3 \pm 3.17$ & $3200 \pm 185.00$ & $29.0 \pm 3.60$ & $650 \pm 8.89$ \\
\hline $\begin{array}{l}\text { Total carbon } \\
(\mathrm{TOC})(\mathrm{mg} / \mathrm{L})\end{array}$ & NA & $4700 \pm 145.26$ & $45070 \pm 1044.46$ & $281 \pm 16.70$ & $23000 \pm 836.48$ \\
\hline $\begin{array}{l}\text { Total nitrogen }(\mathrm{TKN}) \\
(\mathrm{mg} / \mathrm{L})\end{array}$ & NA & $98 \pm 13.45$ & $1700 \pm 149.66$ & $119 \pm 6.24$ & $600 \pm 43.30$ \\
\hline $\mathrm{pH} @ 25^{\circ} \mathrm{C}$ & $6.0-9.0$ & $8.05 \pm 0.05$ & $8.19 \pm 0.17$ & $8.39 \pm 0.11$ & $8.30 \pm 0.11$ \\
\hline \multicolumn{6}{|l|}{ HEAVY METAL } \\
\hline Leads as $\mathrm{Pb}(\mathrm{mg} / \mathrm{L})$ & 0.1 & $0.06 \pm 0.02$ & $0.11 \pm 0.01$ & NA & $0.5 \pm 0.17$ \\
\hline Cadmium as $\mathrm{Cd}(\mathrm{mg} / \mathrm{L})$ & 0.01 & $\mathrm{ND}<0.002$ & $\mathrm{ND}<0.002$ & NA & $\mathrm{ND}<0.002$ \\
\hline Copper as $\mathrm{Cu}(\mathrm{mg} / \mathrm{L})$ & 0.2 & $0.02 \pm 0.01$ & $\mathrm{ND}<0.01$ & NA & $0.12 \pm 0.02$ \\
\hline Iron as $\mathrm{Fe}(\mathrm{mg} / \mathrm{L})$ & 5 & $4.44 \pm 0.11$ & $2.62 \pm 0.11$ & NA & $10.41 \pm 0.74$ \\
\hline Zinc as $\mathrm{Zn}(\mathrm{mg} / \mathrm{L})$ & 2 & $0.18 \pm 0.03$ & $0.19 \pm 0.03$ & NA & $0.80 \pm 0.05$ \\
\hline Magnesium as $\mathrm{Mg}(\mathrm{mg} / \mathrm{L})$ & NA & $23.01 \pm 0.90$ & $180.79 \pm 5.31$ & NA & $186.62 \pm 10.76$ \\
\hline
\end{tabular}

ND: Not detected; NA: Not available

$\mathrm{mg} / \mathrm{L}$ for Landfill No. 1. These observations were in contrast with the finding by Tatsi and Zouboulis (2002) which stated inorganic contaminants also follow the trend of decreasing concentrations with increasing leachate age and stability. Cotman and Gotvajn (2010) reported the concentration of lead decreased with the increasing age of landfill. Besides that, Tatsi and Zouboulis (2002) stated that the concentration of metals in leachate samples were affected by the initial amounts that existed in domestic solid wastes, but they can also be leached by the degradation processes within the landfill. 'Fresh' leachate samples showed a higher degree of metal solubilization due to lower $\mathrm{pH}$ values caused by the biological production of organic fatty acids. The difference in the findings between this study and the study of Tatsi and Zouboulis (2002) may be due to the difference in climate and source of waste disposal. However, as the landfill age increases, the $\mathrm{pH}$ values increases too. This may be caused by a decrease in the concentration of free fatty acids which, due to anaerobic consumption.

This study noted that the principal pollutants in the leachate samples were organic loads; therefore, the best treatment method to treat this leachate is biological treatment. The biological treatment of concentrated leachate was carried-out in flask containing $100 \%$ leachate by immobilized T. menziesii on Ecomat for 28 days. The result of weekly analysis showed that the value of $\mathrm{BOD}_{5}$ was reduced as the incubation time increased. It shows that the removal of $\mathrm{BOD}_{5}$ increased until Day 28 with the highest percentage of $93.48 \%$. It was observed that significant removal of $\mathrm{BOD}_{5}$ occurred at Day $7,82.00 \%$ and gradually increased at Day 14 with BOD $_{5}$ of $87.78 \%$ and $89.14 \%$, respectively. Similarly, the removal of COD occurred at Day 7 at $24.66 \%$ and at Day 21 with COD removal of $2.11 \%$. Table 4 also showed that the value of $\mathrm{NH}_{3}-\mathrm{N}$ increased through-out the experiment until at Day 28 and indicating that no removal of $\mathrm{NH}_{3}-\mathrm{N}$ occurred. The value of $\mathrm{pH}$ shows that the longer the incubation time, the leachate growth medium will became more alkaline.

The results obtained showed the ability of whiterot fungi T. menziesii to remove $\mathrm{BOD}_{5}$ and $\mathrm{COD}$ but not $\mathrm{NH}_{3}-\mathrm{N}$. This finding is coherent with Kim et al. (2003) who reported the use of white-rot fungus $P$. chrysosporium for the biological removal of organics measured as COD. White-rot fungi have been shown to degrade a wide variety of environmental pollutants, including PCP (Walter et al. 2005). Coulibaly et al. (2003) noted that white-rot fungi have been attracting a growing interest for the biotreatment (removal or destruction) of waste water ingredients such as metals, inorganic nutrients and organic compound. This may be due to their capacities to adapt to severe environmental constraints. Basidiomyceteous white-rot fungi are capable of degrading a variety of environmentally pollutants including leachate. This specialty arises 
TABLE 4. Percentage removal of $100 \%$ leachate $\mathrm{BOD}_{5}, \mathrm{COD}, \mathrm{NH}_{3}-\mathrm{N}$ and $\mathrm{pH}$ changes by $T$. menziesii immobilized on Ecomat at weekly intervals for 28 days incubated at room temperature, shaking at $150 \mathrm{rpm}$

\begin{tabular}{|c|c|c|c|c|}
\hline Incubation time & Parameters & $\begin{array}{c}\text { Levels in untreated } \\
\text { leachate }\end{array}$ & $\begin{array}{l}\text { Levels in treated } \\
\text { leachate }\end{array}$ & $\begin{array}{c}\text { Percentage removed (-), } \\
\text { increased }(+)\end{array}$ \\
\hline Day 7 & $\begin{array}{l}\mathrm{BOD}_{5}(\mathrm{mg} / \mathrm{L}) \\
\mathrm{COD}(\mathrm{mg} / \mathrm{L}) \\
\mathrm{NH}_{3}-\mathrm{N}(\mathrm{mg} / \mathrm{L}) \\
\mathrm{pH}\end{array}$ & $\begin{array}{c}11265.00 \\
14600.00 \\
20.4 \\
7.93\end{array}$ & $\begin{array}{r}2028.00 \pm 97.04 \\
11000.00 \pm 991.36 \\
23.47 \pm 0.80 \\
8.82 \pm 0.37\end{array}$ & $\begin{array}{c}-82.00 \\
-24.66 \\
+15.05 \\
+\end{array}$ \\
\hline Day 14 & $\begin{array}{l}\mathrm{BOD}_{5}(\mathrm{mg} / \mathrm{L}) \\
\mathrm{COD}(\mathrm{mg} / \mathrm{L}) \\
\mathrm{NH}_{3}-\mathrm{N}(\mathrm{mg} / \mathrm{L}) \\
\mathrm{pH}^{-}\end{array}$ & $\begin{array}{r}11371.00 \\
14260.00 \\
15.45 \\
7.90\end{array}$ & $\begin{array}{r}1390.00 \pm 41.04 \\
14390.00 \pm 62.45 \\
17.00 \pm 1.51 \\
9.16 \pm 0.14\end{array}$ & $\begin{array}{r}-87.78 \\
+0.91 \\
+10.03 \\
+\end{array}$ \\
\hline Day 21 & $\begin{array}{l}\mathrm{BOD}_{5}(\mathrm{mg} / \mathrm{L}) \\
\mathrm{COD}(\mathrm{mg} / \mathrm{L}) \\
\mathrm{NH}_{3}-\mathrm{N}(\mathrm{mg} / \mathrm{L}) \\
\mathrm{pH}\end{array}$ & $\begin{array}{r}11530.00 \\
13240.00 \\
26.60 \\
7.86\end{array}$ & $\begin{array}{r}1251.67 \pm 54.34 \\
12960.00 \pm 474.45 \\
28.33 \pm 1.59 \\
9.23 \pm 0.18\end{array}$ & $\begin{array}{r}-89.14 \\
-2.11 \\
+6.50 \\
+\end{array}$ \\
\hline Day 28 & $\begin{array}{l}\mathrm{BOD}_{5}(\mathrm{mg} / \mathrm{L}) \\
\mathrm{COD}(\mathrm{mg} / \mathrm{L}) \\
\mathrm{NH}_{3}-\mathrm{N}(\mathrm{mg} / \mathrm{L}) \\
\mathrm{pH}\end{array}$ & $\begin{array}{r}11290.00 \\
14740.00 \\
18.40 \\
7.99\end{array}$ & $\begin{array}{r}736.67 \pm 12.47 \\
15790.00 \pm 246.82 \\
39.90 \pm 2.46 \\
9.38 \pm 0.26\end{array}$ & $\begin{array}{r}-93.48 \\
+7.12 \\
+116.85 \\
+\end{array}$ \\
\hline
\end{tabular}

- indicates reduced (removed); + indicates increased values expressed are means \pm s.d. of triplicate measurements

from the production of powerful oxidative and nonspecific extracellular enzymes known as peroxidases. The peroxidases families are best recognized by lignin peroxidases $(\mathrm{LiP})$, manganese peroxidases $(\mathrm{MnP})$ and aryl alcohol oxidase (AAO) (Pozdnyakova et al. 2011). Previous result (Noorlidah et al. 2013) shows that whiterot fungus Ganoderma australe was able to produce ligninolytic enzymes such as LiP, MnP and Laccase. These enzymes were known for their ability to degrade a variety of environmental pollutants that include leachate. The ability of these enzymes to degrade a variety of industrial pollutants, environmental pollutants and leachate was also supported by Turkdogan-Aydinol et al. (2011).

\section{CONCLUSION}

Our study indicated that large variations exist in the characteristics of leachates from different types of landfills (in this case closed and active landfills) in terms of their physicochemical parameters. All the parameters studied were lower in leachate from closed landfills than leachate from active landfills except $\mathrm{pH}$ and ammoniacal nitrogen. Consequently, these results showed the difficulty in leachate treatment. With reference to the discharge limit of $400 \mathrm{mg} / \mathrm{L}$ for COD and $5 \mathrm{mg} / \mathrm{L}$ for $\mathrm{NH}_{3}$, it was suggested that these landfills leachate need further treatment before they can be discharged to the nearby environment. This study showed that the principal pollutants in the leachate samples were organic loads; therefore, biological treatment is the best treatment method. The application of biological treatment using immobilized T. menziesii showed a promising potential to be used in leachate treatment since significant removal of $\mathrm{BOD}_{5}(89.14 \%)$ and COD $(2.11 \%)$ were observed after 28 days.

\section{REFERENCES}

Al-Muzaini, S. 2006. Characteristics of leachate at the Qurain dumping site. Journal of Food, Agriculture \& Environment 4: 251-254.

APHA. 1998. Standard Methods for the Examination of Water and Wastewater. 20th ed. Washington, D.C.: American Public Health Association.

Baun, A., Ledin, A., Reitzel, L.A., Bjerg, P.L. \& Christensen, T.H 2004. Xenobiotic organic compounds in leachates from ten Danish MSW landfills-chemical analysis and toxicity tests. Water Research 38: 3845-3858.

Bilgili, M.S., Demir,A. \& Ozkaya, B. 2007. Influence of leachate recirculation on aerobic and anaerobic decomposition of solid wastes. Journal of Hazardous Materials 143: 177-183.

Chu, L., Cheung, K. \& Wong, M. 1994. Variations in the chemical properties of landfill leachate. Environmental Management 18: 105-117.

Cotman, M. \& Gotvajn, A.Z. 2010. Comparison of different physico-chemical methods for the removal of toxicants from landfill leachate. Journal of Hazardous Materials 178: 298-305.

Coulibaly, L., Gourene, G. \& Agathos, S.N. 2003. Utilization of fungi for biotreatment of raw wastewaters. African Journal of Biotechnology 2: 620-630.

Deng, Y. 2007. Physical and oxidative removal of organics during Fenton treatment of mature municipal landfill leachate. Journal of Hazardous Materials 146: 334-340.

Ding, A., Zhang, Z., Fu, J., Cheng, L. \& Zhang, Z. 2001. Biological control of leachate from municipal landfills. Chemosphere 44: 1-8.

Edi Munawar \& Fellner, J. 2013. Guidelines for Design and Operation of Municipal Solid Waste Landfills in Tropical Climates: ISWA - the International Solid Waste Association.

El-Fadel, M., Bou-Zeid, E., Chahine, W. \& Alayli, B. 2002. Temporal variation of leachate quality from pre-sorted and baled municipal solid waste with high organic and moisture content. Waste Management 22: 269-289. 
Environmental Quality Act (EQA). 2009. Control of pollution from solid waste transfer station and landfill, Regulation 13 (2009) Schedule 2], under the Laws of Malaysia. Malaysia Environmental Quality Act 1974, Minister of Natural Resources and Environmental, Malaysia.

Eugenio, M.E., Carbajo, J.M., Terrón, M.C., González, A.E. \& Villar, J.C. 2008. Bioremediation of lignosulphonates by lignin-degrading basidiomycetous fungi. Bioresource Technology 99: 4929-4934.

Faeiza Haji Buyong, Mohamad Syarizal Abdul Kadir \& Fairus Muhammad Darus. 2004. Comparison of selected parameters of leachate in different age of closed landfills. 17th Analysis Chemistry Malaysia Symposium. Swiss-Garden Resort \& Spa, Kuantan, Pahang, Malaysia.

Jemec, A., Tišler, T. \& Žgajnar-Gotvajn, A. 2012. Assessment of landfill leachate toxicity reduction after biological treatment. Archives of Environmental Contamination and Toxicology 62: 210-221.

Kamaruddin, M.A., Yusoff, M.S., Abdul Aziz, H. \& Hung, Y.T. 2014. Sustainable treatment of landfill leachate. Applied Water Science DOI: 10.1007/s13201-014-0177-7.

Kang, K.H., Shin, H.S. \& Park, H. 2002. Characterization of humic substances present in landfill leachates with different landfill ages and its implications. Water Research 36: 40234032.

Kim, Y.K., Park, S.K. \& Kim, S.D. 2003. Treatment of landfill leachate by white rot fungus in combination with zeolite filters. Journal of Environmental Science and Health - Part A Toxic/Hazardous Substances and Environmental Engineering 38: 671-683.

Kjeldsen, P., Barlaz, M.A., Rooker, A.P., Baun, A., Ledin, A. \& Christensen, T.H. 2002. Present and long-term composition of MSW landfill leachate: A review. Critical Reviews in Environmental Science and Technology 32: 297-336.

Kotterman, M., Wasseveld, R.A. \& Field, J.A. 1996. Hydrogen peroxide production as a limiting factor in xenobiotic compound oxidation by nitrogen-sufficient cultures of Bjerkandera sp. strain BOS55 overproducing peroxidases. Applied and Environmental Microbiology 62: 880-885.

Leonowicz, A., Matuszewska, A., Luterek, J., Ziegenhagen, D., Wojtas-Wasilewska, M., Cho, N.S., Hofrichter, M. \& Rogalski, J. 1999. Biodegradation of lignin by white rot fungi. Fungal Genetic and Biology 27: 175-185.

Marttinen, S.K., Kettunen, R.H., Sormunen, K.M., Soimasuo, R.M. \& Rintala, J.A. 2002. Screening of physical-chemical methods for removal of organic material, nitrogen and toxicity from low strength landfill leachates. Chemosphere 46: 851-858.

Miller, P.A. \& Clesceri, N.L. 2003. Waste Sites as Biological Reactors: Characterization and Modeling. Florida: Lewis Publishers, CRC Press.

Noorlidah Abdullah, Wan Razarinah, W.A.R., Noor Zalina Mahmood \& Rosna Mat Taha. 2013. Treatment of landfill leachate using Ganoderma australe mycelia immobilized on Ecomat. International Journal of Environmental Science and Development 4: 483-487.

Pointing, S.B. 2001. Feasibility of bioremediation by white-rot fungi. Mini-review. Applied and Environmental Microbiology 57: 20-33.

Polak, J. \& Jarosz-Wilkołazka, A. 2010. Whole-cell fungal transformation of precursors into dyes. Microbial Cell Factories 9: 51.
Pozdnyakova, N.N., Dubrovskaya,E.V., Makarov, O.E., Nikitina, V.E. \& Turkovskaya, O.V. 2011. Production of ligninolytic enzymes by white-rot fungi during bioremediation of oilcontaminated soil. Soil Biology 22: 363-377.

Saetang, J. \& Babel, S. 2010. Fungi immobilization for landfill leachate treatment. Water Science and Technology 62(6): 1240-1247.

Saetang, J. \& Babel, S. 2009. Effect of leachate loading rate and incubation period on the treatment efficiency by $T$. versicolor immobilized on foam cubes. International Journal of Environment Science and Technology 6(3): 457-466.

Samudro, G. \& Mangkoedihardjo, S. 2010. Review on BOD, $\mathrm{COD}$ and $\mathrm{BOD} / \mathrm{COD}$ ratio: A triangle zone for toxic, biodegradable and stable levels. International Journal of Academic Research 2: 235-239.

Sanitary landfills. 2009. http://www.whbenvironment.com. Accessed on April 14, 2009.

Slack, R.J., Gronow, J.R. \& Voulvoulis, N. 2005. Household hazardous waste in municipal landfills: Contaminants in leachate. Science of the Total Environment 337: 119-137.

Tatsi, A.A. \& Zouboulis, A.I. 2002. A field investigation of the quantity and quality of leachate from a municipal solid waste landfill in a Mediterranean climate (Thessaloniki, Greece). Advances in Environmental Research 6: 207-219.

Turkdogan-Aydinol, F.I., Yetilmezsoy, K. \& Comez, S. 2011. Effect of extracellular enzyme activity on digestion performance of mesophilic UASB reactor treating highstrength municipal wastewater. Bioprocess and Biosystems Engineering 34(4): 389-401.

Waites, M.J., Morgan, N.L., Rockey, J.S. \& Higton, G. 2001. Industrial Microbiology: An Introduction. London: Blackwell Science Ltd.

Walter, M., Boyd-Wilson, K., Boul, L., Ford, C., McFadden, D., Chong, B. \& Pinfold, J. 2005. Field-scale bioremediation of pentachlorophenol by Trametes versicolor. International Biodeterioration \& Biodegradation 56: 51-57.

Zouboulis, A.I., Loukidou, M.X. \& Christodoulou, K. 2001. Enzymatic treatment of sanitary landfill leachate. Chemosphere 44: 1103-1108.

W.A.R. Wan Razarinah*, M. Noor Zalina \& Noorlidah Abdullah Mushroom Research Centre, University of Malaya Faculty of Science, Institute of Biological Sciences 50603 Kuala Lumpur Malaysia

W.A.R. Wan Razarinah*

Faculty of Applied Sciences

MARA University of Technology

40450 Shah Alam, Selangor Darul Ehsan

Malaysia

*Corresponding author; email: razarina408@yahoo.com

Received: 22 April 2014

Accepted: 30 August 2014 